\title{
Personalized Allocation of English Teaching Resources through Weight Calculation Based on Term Frequency- Inverse Document Frequency
}

\author{
https://doi.org/10.3991/ijet.v15i10.13335 \\ Yuxin Tian \\ Northwest University, Xi'an, China \\ yuxin202@163.com
}

\begin{abstract}
The allocation of English teaching resources is the key to education equity. Effective utilization of teaching resources helps to diversify learning channels, improve learning methods and promote teaching effect. This paper attempts to develop a method to allocate English teaching resources according to local conditions, providing a guarantee of education equity. Firstly, the author explored the current allocation strategy of English teaching resources, and divided English teaching resources into integrated resource, material resource and human resource. Then, the weight calculation based on term frequency-inverse document frequency (TF-IDF) was adopted to allocate English teaching resources, in the light of personal demand. The proposed method was verified through questionnaire survey and statistical analysis. The results show that, the IDF reduces the importance of eigenvalues in most processes of resource allocation; the TF-IDF-based weight calculation is suitable for the personalized allocation of English teaching resources in different regions and under different faculty levels; it is possible to fully utilize different types of English teaching resources through personalized allocation, based on certain allocation principles. This paper provides a reference for personalized allocation of real-world English teaching resources.
\end{abstract}

Keywords-English teaching resources, term frequency-inverse document frequency (TF-IDF), personalized allocation, resource allocation

\section{Introduction}

English is an international language and the most widely spoken language in the world. It provides students with positive, up-to-date and informative curriculum resources that are consistent with their personality and practical conditions [1,2]. With the help of network technology and modern education technology, new English learning and application channels could be explored by actively utilizing the rich teaching resources such as multi-media, television, books, and magazines, etc. [3]. The allocation of English teaching resources is related to education equity. The personalized design and development of English resources can help students create and control teaching scenarios, mobilize their senses, and free them from the dull and monotonous 
written languages and receive the large amount of English resources more effectively $[4,5]$. During English teaching, English teaching resources have broad application prospects in the aspects of scenario creation, learning mode innovation, interactive design, learning space expansion, and classroom activities, etc. [6].

The TF-IDF weight calculation method is the most widely used eigen-weight calculation method in the field of resource allocation. TF can well identify high-frequency features, and IDF reduces the importance of eigenvalues that appear in most resource allocation processes [7]. The TF-IDF weight calculation method can analyze from the aspects of the feature term frequency of resource allocation, the inverse resource allocation frequency, and the data normalization frequency of resource allocation, etc., but this method hasn't considered the distribution of resource allocation feature terms within the category $[8,9]$. Personalized teaching resources can be material or immaterial, tangible or intangible, it supports personalized allocation of all resources in the English teaching activities, in this process, the non-human resources include various medias, auxiliary teaching facilities, etc., and all teaching resources will have a positive impact on the teaching processes $[10,11]$. At present, the development and utilization rate of English teaching resources is relatively low, and the phenomenon of resource waste is extremely serious. To achieve education equity according to local conditions, the TF-IDF weight calculation method of resource allocation is the most suitable method for English teaching resource allocation $[12,13]$. Based on the TF-IDF weight calculation method, this paper explores the current allocation strategy of English teaching resources, and applies the TF-IDF weight calculation method to achieve the personalized allocation of English teaching resources. This study provides a theoretical basis and method for enhancing real-world personalized allocation of English teaching resources.

\section{TF-IDF Eigen-Weight Calculation Method}

The TF-IDF eigen-weight method has a good ability in recognition of high-frequency features. In teaching resource allocation, the formula for calculating the eigenweight is shown as Formula 1:

$$
\mathrm{W}_{\mathrm{ik}}=\mathrm{tf}_{\mathrm{ik}}\left(\mathrm{t}_{\mathrm{k}}\right) * \mathrm{idf}\left(\mathrm{t}_{\mathrm{k}}\right)=\mathrm{f}_{\mathrm{ik}}\left(\mathrm{t}_{\mathrm{k}}\right) \log \left(\mathrm{N} / \mathrm{n}_{\mathrm{k}}+\mathrm{l}\right)
$$

In order to prevent the TF-IDF algorithm from the tendency to longer documents, the calculation formula is normalized as:

$$
\operatorname{TFIDF}(\text { wik })=\frac{t f i k\left(t_{k}\right) \times \log \left(\frac{N}{n_{k}}+l\right)}{\sqrt{\sum_{k=1}^{n}\left(t f i k\left(t_{k}\right) \times \log \left(\frac{N}{n_{k}}+l\right)\right)}}
$$

where, $t_{k}$ represents a feature word, $d_{i}$ represents the text paragraph, and $w_{i k}$ represents the weight.

Figure 1 shows the TF-IDF weight calculation method. During the allocation of English teaching resources, the teaching-centered exploratory learning mode is adopted by the learners and they can use the teaching resources repetitively for learning. In the 
entire resource allocation process, problems are discovered, recognized and integrated. Larger resource value of the allocation feature term indicates higher fitness of the teaching resource and the English teaching.

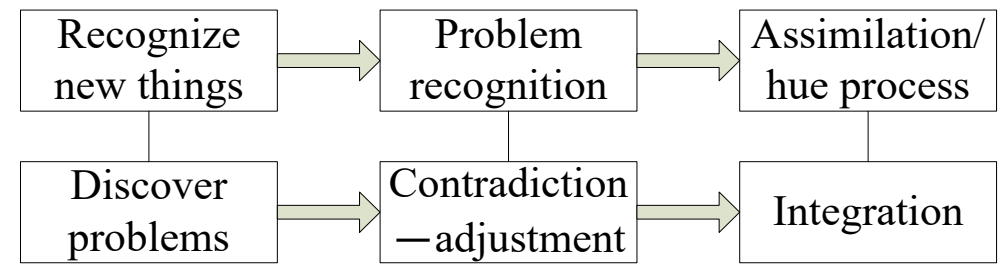

Fig. 1. TF-IDF weight calculation method

\section{$3 \quad$ Allocation of English Teaching Resources}

\subsection{Current status of the application of English teaching resource and existing problems}

At present, education facilities and methods are expanding and innovating continuously, and how to make English teaching resources adapt to local conditions and achieve personalized teaching are the focus of the research of teaching resource allocation [14]. With the development of network technology, the Internet is the most abundant one of all teaching resources. In English teaching and learning, teachers and students can choose learning contents and learning methods according to their own needs $[15,16]$. Many schools attach great importance to English education and invest a lot of manpower and materials for this purpose, but the overall effect is not obvious [17]. A survey of high school students in four high schools in Jiangxi Province found that their learning purposes are different, as shown in Figure 2, their learning purposes include English material reading, English movie or tv program watching, going abroad and communicating with foreigners, etc. Figure 3 shows the English teaching resources of the four high schools in Jiangxi Province. It can be clearly seen that the teaching resources of each high school differ from each other, but all are equipped with sound labs, libraries, multimedia classrooms, and digital reading rooms, etc.

At present, there are still many problems in the allocation of English teaching resources. Figure 4 shows the problems in the utilization of English teaching resources. First, teachers' understanding of the teaching resources is insufficient; second, teaching resources are not as varied; in the teaching process, teachers do not take the initiative to make use of the teaching resources to enrich their teaching contents, they are lacking in the exploration and proper utilization of new knowledge and new resources, the form of homework is monotonous, and the content of homework is not diverse; third, teachers can't guide students to explore and discover the teaching resources, and in this process, teachers neglect the importance of teaching resources to the teaching activities, and often ignore the positive role of the rich course content in promoting the initiative 
in English learning; moreover, English teachers won't encourage students to explore English teaching resources on their own.

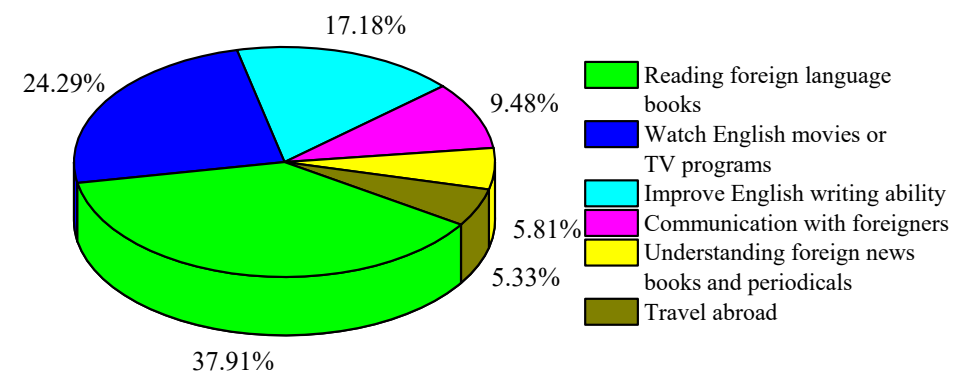

Fig. 2. English learning purposes

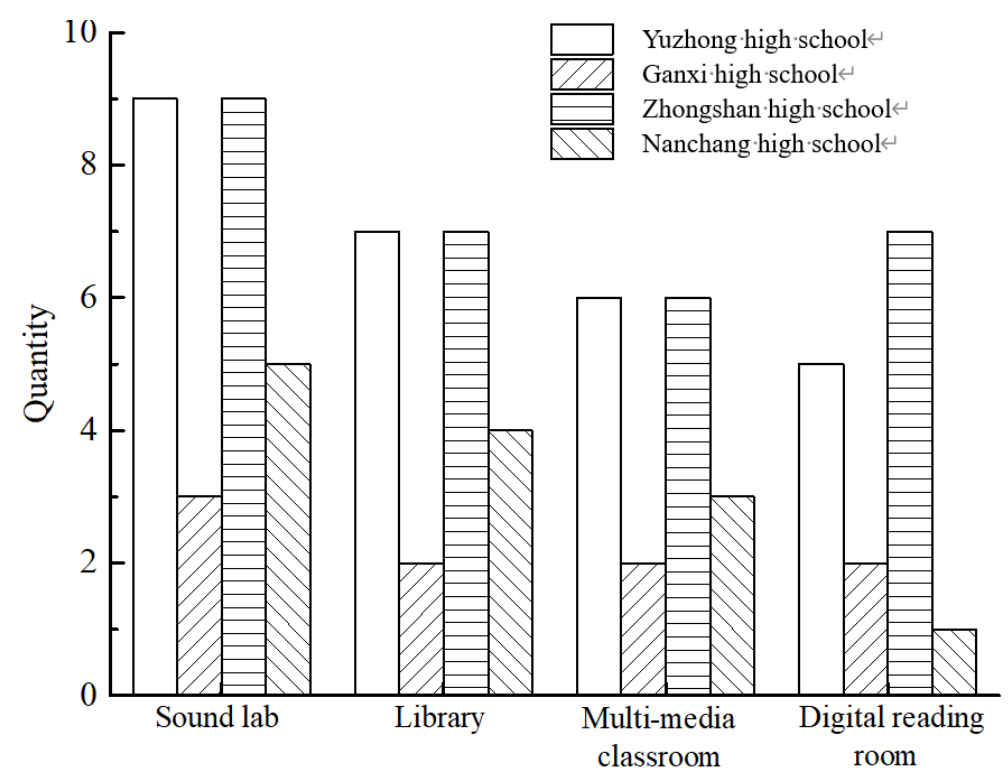

Fig. 3. English teaching resources of four high schools in Jiangxi Province 




Fig. 4. Problems in the utilization of English teaching resources

\subsection{Principles and basic types of English teaching resources}

Figure 5 shows the system of English teaching resources, which is divided into three categories: integrated resource, material resource, and human resource.

Integrated material

teaching resources Material material



Human teaching resources

Fig. 5. English teaching resource system

Wherein, the integrated resource includes English textbooks, multimedia courseware, question banks and online courses, etc.; material resource includes extracurricular English materials, English lectures and corpora, etc.; and human resource includes teachers, teaching assistants, and school mates, etc. The basic types of English teaching resources are shown in Figure 6, including the rich and precious student 
resource, the cultured and profound teacher resource, the open and diverse teaching material resource, the multi-dimensional integrated information resource, and the rich and substantial extracurricular English resource. Figure 7 shows the principles for the personalized allocation of English teaching resources, including the principles of pertinent, open, adaptable, developmental, and economic. In the process of English teaching, rich extracurricular resources, English magazines, English films and tv programs, and online courses are all indispensable parts of the English learning process [18].

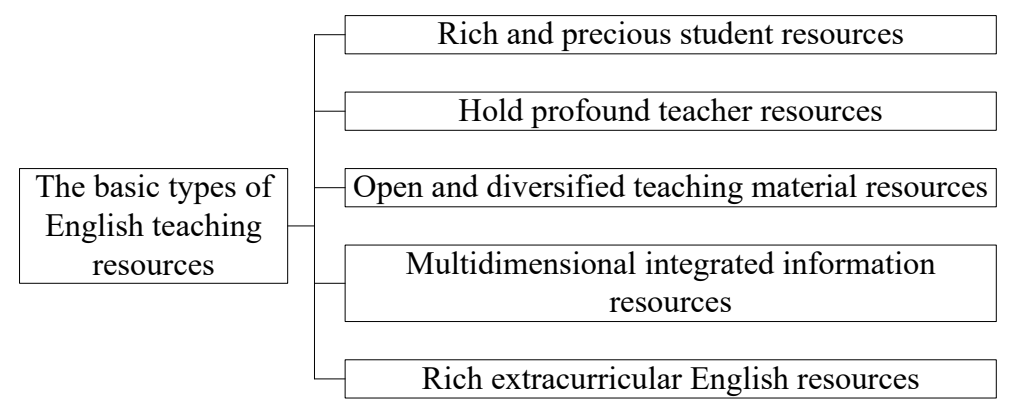

Fig. 6. Basic types of English teaching resources

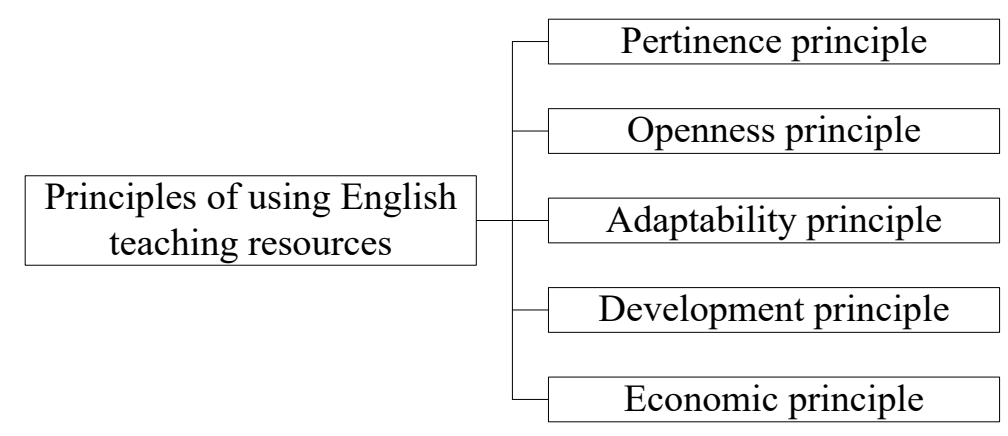

Fig. 7. Principles for the personalized allocation of English teaching resources

\section{Implementation of Personalized Allocation of English Teaching Resources Based on TF-IDF Weight Calculation Method}

\subsection{Research design}

In order to explore the application of TF-IDF weight calculation method to the personalized allocation of English teaching resources, this paper adopts questionnaires and statistics to investigate the evaluation of teachers and students on the English teaching resources. Through the recognition and attitudes of teachers and students towards English teaching resources, we can evaluate whether the TF-IDF weight calculation method 
is feasible or not. The respondents are from four high schools in Jiangxi Province. Table 1 is the basic information of teacher respondents, and Table 2 is the basic information of student respondents. Questionnaires for teachers include the degree of application of teaching resources, students' responses, teaching effect, and problems in the development and application of English teaching resources; while the questionnaires for students include basic English leaning status, recognition of English teaching resources, application of auxiliary teaching resources, and responds to the application effect of teaching resources, etc. This paper also selects a high school with insufficient teaching resources, and compares the average English scores of the students in this school with the English scores of the four high schools investigated in this study.

Table 1. Basic information of teacher respondents

\begin{tabular}{|l|l|c|c|}
\hline \multicolumn{1}{|c|}{ Type } & \multicolumn{1}{|c|}{ Category } & Quantity & Percentage/\% \\
\hline \multirow{3}{*}{ Gender } & Male & 26 & $37.68 \%$ \\
\cline { 2 - 4 } & Female & 43 & $62.32 \%$ \\
\hline \multirow{4}{*}{ Age } & $25-35$ & 24 & $34.78 \%$ \\
\cline { 2 - 4 } & $35-45$ & 36 & $52.17 \%$ \\
\cline { 2 - 4 } & $>45$ & 9 & $13.04 \%$ \\
\hline \multirow{3}{*}{ Education level } & Undergraduate & 52 & $75.36 \%$ \\
\cline { 2 - 4 } & Postgraduate and above & 17 & $24.64 \%$ \\
\hline \multirow{3}{*}{ Academic title } & Primary & 38 & $55.07 \%$ \\
\cline { 2 - 4 } & Intermediate & 27 & $39.13 \%$ \\
\cline { 2 - 4 } & Senior & 4 & $5.80 \%$ \\
\hline
\end{tabular}

Table 2. Basic information of student respondents

\begin{tabular}{|l|l|c|c|}
\hline \multicolumn{1}{|c|}{ Type } & \multicolumn{1}{|c|}{ Category } & Quantity & Percentage/\% \\
\hline \multirow{2}{*}{ Gender } & Male & 126 & $52.5 \%$ \\
\cline { 2 - 4 } & Female & 114 & $47.5 \%$ \\
\hline \multirow{2}{*}{$\begin{array}{l}\text { Whether to assist English teaching } \\
\text { resources }\end{array}$} & Yes & 156 & $65 \%$ \\
\cline { 2 - 4 } & No & 84 & $35 \%$ \\
\hline \multirow{3}{*}{ Class } & Senior grade one & 81 & $33.75 \%$ \\
\cline { 2 - 4 } & Senior grade two & 83 & $34.58 \%$ \\
\cline { 2 - 4 } & Senior grade three & 76 & $31.67 \%$ \\
\hline
\end{tabular}

\subsection{Result analysis}

Figure 8 shows teachers' attitudes towards English teaching resources. $76.92 \%$ of teachers believe that English teaching resources are necessary for English teaching, which means that most teachers think that English teaching resources are meaningful. With the rapid development and application of multimedia technology, more multimedia teaching resources are adopted in the English teaching process, including the teaching CDs come with the textbooks, PPTs, language labs, online English teaching resources, English radio programs, multimedia teaching database, videotapes of famous teachers, English films and multimedia teaching equipment, etc. The specific situations of the application of multimedia resources by teachers during English teaching is shown 
in Figure 9. Teachers are more inclined to use resources such as the teaching CDs of the textbooks, PPTs, and language labs, etc.; while they seldom use English films or multimedia teaching equipment. According to the survey results of teachers, it can be concluded that teachers are more inclined to use auxiliary English teaching resources.

Students exhibit a positive attitude towards the utilization of teaching resources. Figure 10 shows students' preferences for auxiliary English teaching resources. Figure 10 (a) shows students' evaluation on English teaching when there isn't any auxiliary teaching resource, it can be clearly seen that only $30 \%$ of students expressed their fondness for English teaching in the evaluation; Figure 10 (b) shows students' evaluation on English teaching when there're auxiliary teaching resources, more than $70 \%$ of students expressed that they like it or like it very much in the evaluation. This shows that students expressed a positive attitude towards auxiliary English teaching resources. Figure 11 is the survey results of students 'satisfaction with English courses, it can be seen that most of the students expressed that they are satisfied or very much satisfied with the English courses after applying the auxiliary teaching resources; in terms of "English speaking" in the English teaching, the proportion of students who are very much satisfied with the English teaching is the largest, that is, the auxiliary English teaching resources can help students improve their ability in oral English. Figure 12 shows the impact of personalized allocation and application of teaching resources on the pass rate of English exams, it can be clearly seen that in the three high-school grades, the English exam pass rate of students who had used the English teaching resources was higher than that of those who had not used the English teaching resources. Therefore, it is very important to realize the personalized allocation of English teaching resources, and the TF-IDF weight calculation method is very suitable for the personalized allocation of English teaching resources in different regions with different teacher resources.

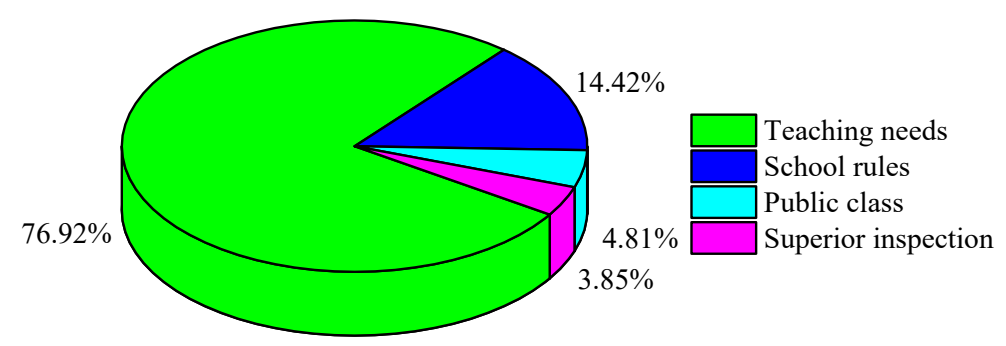

Fig. 8. Teachers' attitude towards English teaching resources 


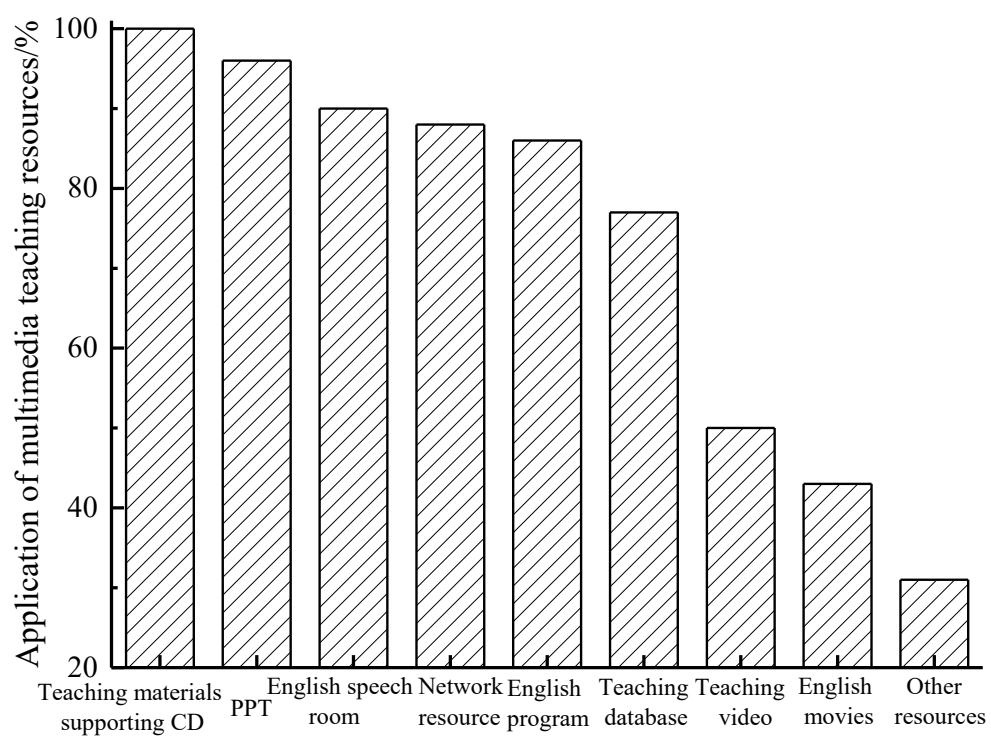

Fig. 9. Application of multimedia resources by teachers during English teaching



(a) Without auxiliary English teaching resources

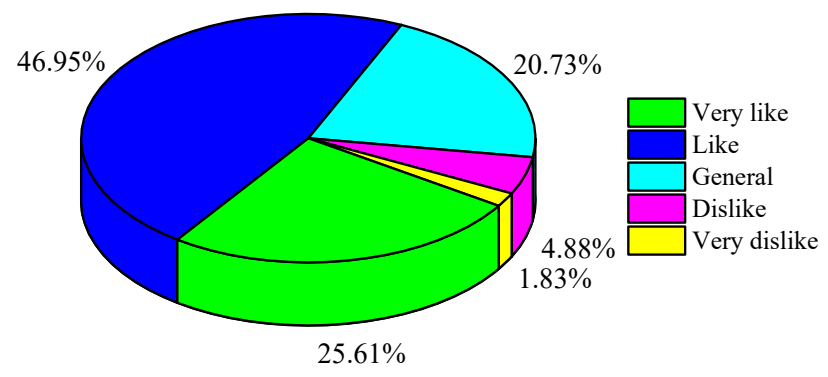

(b) With auxiliary English teaching resources

Fig. 10. Evaluation of students' preference for auxiliary English teaching resources 


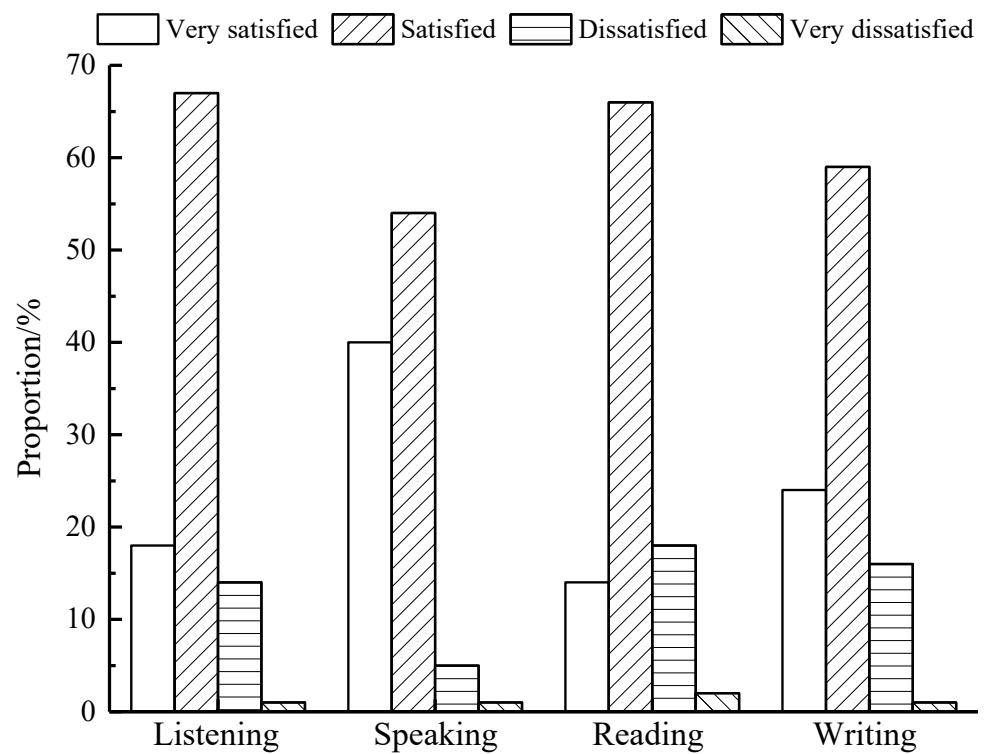

Fig. 11. Survey results of students' satisfaction with English courses

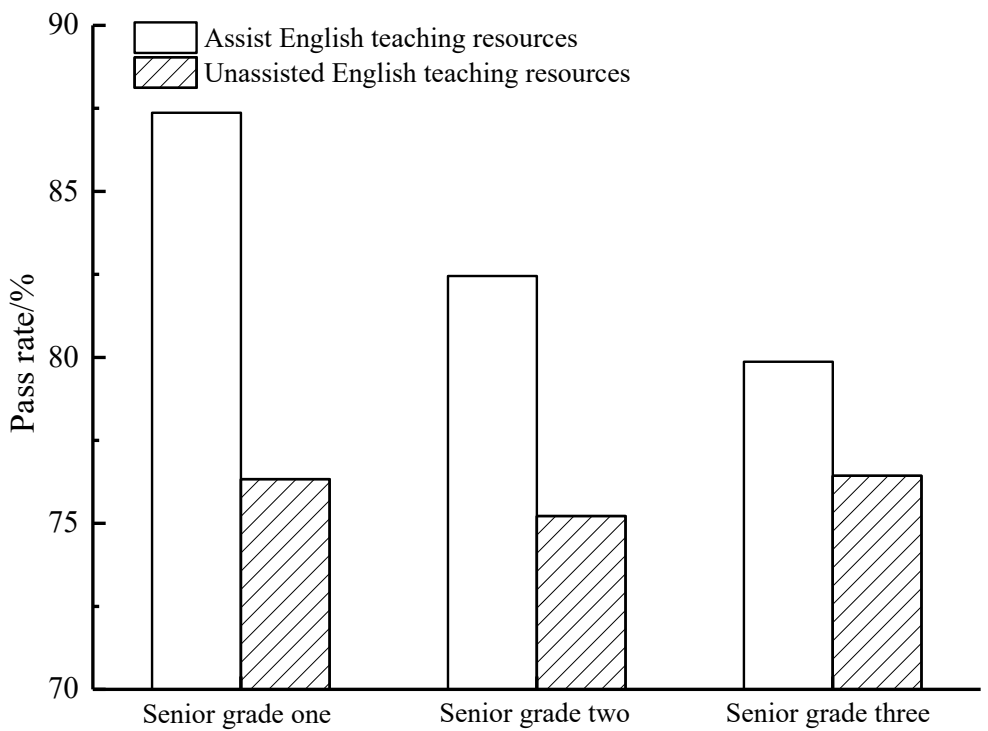

Fig. 12. Impact of personalized allocation and application of teaching resources on English exam pass rate 


\subsection{Suggestions and countermeasures for personalized allocation of English teaching resources}

There are large gaps in the student level, faculty level, and teaching resources among different schools, to maximize the efficiency of English teaching with limited resources, it's necessary to achieve personalized allocation of English teaching resources. Figure 13 shows the countermeasures for the personalized allocation of English teaching resources, which are carried out from the two aspects of the application of teaching resources and the guarantee of teaching resources. First, in terms of teaching resource application, we should encourage students to share the resources, renew our ideas, organize the teaching content in accordance with the needs of students, build a rich foreign language learning database, strengthen resource management, enhance systematic operation of English teaching resources, and improve teachers' awareness for the resources and their personal qualities, etc. Second, in terms of the teaching resource guarantee, we should enhance teachers' awareness for the courses, awaken students' subjective consciousness, speed up the construction of teaching materials and adopt multiple evaluation methods.



Fig. 13. Countermeasures for personalized allocation of English teaching resources

\section{Conclusion}

Based on the TF-IDF weight calculation method, this paper explored the current status of the allocation of English teaching resources, and adopted the TF-IDF weight calculation method to achieve personalized allocation of English teaching resources. The specific conclusions are as follows: 
1. During the allocation of English teaching resources, the teaching-centered exploratory learning mode is adopted by the learners and they can use the teaching resources repetitively for learning. In the entire resource allocation process, larger resource value of the allocation feature term indicates higher fitness of the teaching resource and the English teaching.

2. The system of English teaching resources is divided into three categories: integrated resource, material resource, and human resource; and the personalized allocation of English teaching resources must follow the principles of pertinent, open, adaptable, developmental, and economic.

3. Both teachers and students are inclined to use auxiliary English teaching resources, and they gave a high evaluation to the English teaching resources. The TF-IDF weight calculation method is very suitable for the personalized allocation of English teaching resources in different regions with different teacher resources.

\section{Acknowledgement}

This paper was supported by Research on Chinese Language Learning Motivation: Performance and Perception of Students from "Belt and Road" Countries (No. 19JK0820).

\section{$7 \quad$ References}

[1] Wang, Y., Wu, L. (2014). College English classroom teaching design based on DDL. 2014 Fourth International Conference on Instrumentation and Measurement, Computer, Communication and Control (IMCCC), 109-122. https://doi.org/10.1109/imccc.2014.30

[2] Zhan, J.H., Li, C.X., Nie, W.X. (2011). Advantages and problems of multimedia-based college English teaching mode. Advanced Materials Research, 271-273: 1644-1646. https ://doi.org/10.4028/www.scientific.net/amr.271-273.1644

[3] Cao, C.L. (2015). Construction of the personalized college English learning management system using ruby on rails. 2015 International Conference on Service Science (ICSS), 160163. https://doi.org/10.1109/icss.2015.22

[4] Lee, M., Geelhoed, E. (2011). Teaching resource allocation--and why it matters. Virtual Mentor, 13(13): 224-227.

[5] Liu, Y. (2018). Research on optimized allocation of English teaching resources based on network cloud platform. 2018 International Conference on Intelligent Transportation, Big Data \& Smart City (ICITBS), 351-354. https://doi.org/10.1109/icitbs.2018.00096

[6] Jin, G., Bierma, T., Yang, L. (2016). Cap-and-trade: understanding and teaching a marketbased approach to natural resource allocation. Journal of Natural Resources and Life Sciences Education, 45(1): 1-11. https://doi.org/10.4195/nse2015.0030

[7] Gonzalez, P.F., Ochoa, C.A., Cabrera, P.A., Castillo, L.M., Arias, M.O. (2015). EFL teaching in the amazon region of Ecuador: a focus on activities and resources for teaching listening and speaking skills. English Language Teaching, 8(8): 94-103. https://doi.org/10. 5539/elt.v8n8p94

[8] Lou, M. (2017). Design of English multimedia teaching system based on diversification theory. International Journal of Emerging Technologies in Learning, 12(1): 119-129. 
[9] Negash, M. (2013). Resource allocation challenges in south African universities: a management accounting perspective. Social Science Electronic Publishing, 3(2): 265-292.

[10] Gaertner, J., Maier, B.O., Radbruch, L. (2015). Resource allocation issues concerning early palliative care. Annals of Palliative Medicine, 4(3): 156-161.

[11] Xu, Y.F., Lijun, L., Qingsong, H., Tiewei, F.U. (2017). Research on TF-IDF weight improvement algorithm in intelligent guidance system. Computer Engineering and Applications, 53(4): 238-243.

[12] Yue, H., Gan, M., Jiang, R. (2012). Ontology-based genes similarity calculation with TFIDF. Proceedings of the Third international conference on Information Computing and Applications, 7473(1): 608-615. https://doi.org/10.1007/978-3-642-34062-8 78

[13] Tu, S.Z., Huang, M.L. (2016). Mining microblog user interests based on text rank with TFIDF factor. The Journal of China Universities of Posts and Telecommunications, 23(5): 4450. https://doi.org/10.1016/s1005-8885(16)60056-0

[14] Al-Issa, A.S., Al-Bulushi, A.H. (2012). English language teaching reform in sultanate of oman: the case of theory and practice disparity. Educational Research for Policy and Practice, 11(2), 141-176. https://doi.org/10.1007/s10671-011-9110-0

[15] Hayes, D. (2009). Non-native English-speaking teachers, context and English language teaching. System, 37(1): 1-11. https://doi.org/10.1016/j.system.2008.06.001

[16] Briggs, A. (2014). Rational allocation of resources available for healthcare: understanding cost effectiveness analyst. Journal of the International AIDS Society, 17: 19492. https:// doi.org/10.7448/ias.17.4.19492

[17] Martinez, J.A., Navas-Carretero, S., Saris, W.H.M., Astrup, A. (2014). Personalized weight loss strategies-the role of macronutrient distribution. Nature Reviews Endocrinology, 10(12): 749-760. https://doi.org/10.1038/nrendo.2014.175

[18] Duan, M.Z.., Yang, Z.S., Zhang, L., Tian, X.J. (2017). Parking spaces allocation model of residential areas sharing parking based on personalized guidance. Journal of Northeastern University, Natural Science, 38(2): 174-179.

\section{Author}

Yuxin Tian (1988.2) Female, was born in Shaanxi Xi'an. She graduated from New York University, M.A. in TESOL. Now, she works at School of International Education, Northwest University. Her main research interests include Second Language Acquisition, Second Language Teaching and Technology, Intercultural Communication. During work, she leads the Social Science Research Project funded by the Shaanxi Education Department and was a key participant of the Social Science Project funded by the Shaanxi Academy of Social Sciences.

Article submitted 2020-01-22. Resubmitted 2020-02-27. Final acceptance 2020-02-28. Final version published as submitted by the authors. 